\title{
繊維系断熱材中の真菌の移動性状に関する基礎的研究
}

\section{A BASIC STUDY ON CHARACTERISTICS OF MOLD MOVEMENT IN GLASS WOOL HEAT INSULATING MATERIALS}

\author{
山田裕已*, 林基哉**, 田辺新一***, \\ 大 澤 元 毅**，長谷川 兼一****，本 間 義 規**** \\ Hiromi YAMADA, Motoya HAYASHI, Shin-ichi TANABE, \\ Haruki OSAWA, Ken-ichi HASEGAWA and Yoshinori HONMA
}

\begin{abstract}
It is necessary to insulate a building envelope in order to improve the indoor environment and to save energy consumption in houses. However, if vapor protection or an airtight seal is not perfect, condensation decreases the durability of the structure and lowers the indoor air quality. The air pollutants enter from concealed spaces (beam space, crawl space, etc.) to the indoor space through indoor decompression in the ventilation system. If mold infiltrates through the glass wool heat insulating materials, some of the mold may stay and grow. The objective of the present investigation is to characterize the movement of mold spores between heat insulators.

It is concluded that the sampling method for the concealed space must use a Teflon tube that is about $0.3 \mathrm{~m}$ long. The heat insulator was washed using sterilized physiological salt solution to clarify the movement of mold spores in a heat insulator. The amount of mold spores in the heat insulator decreased with an increase in the number of times it was washed. After the third washing, the desorption rate of mold spores in the heat insulator was about $85 \%$. Hence, three rounds of washing were required to measure the mold movement in glass wool heat insulators. For movement of mold spores inside the heat insulator, the quantity of mold spores adhering to the heat insulator decreases exponentially with an increase in length. In this range of the wind velocity, it was found that the movement of mold spores between insulators through the heat insulator is not significantly influenced by wind in the small chamber.
\end{abstract}

Keywords : Indoor air quality, Mold, Sampling method, Teflon tube, Heat insulator, Movement 室内空気質，真菌，採取法，テフロンチューブ，断熱材，移動

\section{1. はじめに}

住宅内の居住環境において真菌が問題となっており、特に高湿環 境や有機物の多い污れ部屋、空気が滞留する場所における污染発生 が指摘されている 1)。居室内の気中の真菌リスクは予測カビ指数を 用いることで評価が可能となっており 2),3)、リスク低減のための室

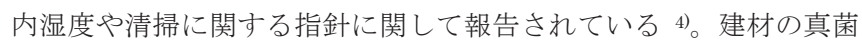
の増殖リスクに関しては、建材が置かれた雰囲気環境のみならず、 素材の構成との関連が指摘されており、例えば畳のように多孔質な 建材に関しては低温域から高温域に至る状況の真菌の成長が確認さ れている5)。

居室の室内空気污染は、室内の污染物質発生源のみに依存せず、 床下をはじめ天井裏、壁体内部等の躯体内部空間の影響が指摘され ている。これは気密化された在来木造軸組構法や木造枠組構法にお いても床下、外壁内部、間仕切内部、天井裏、室内空間を介する複
雑な通気経路が存在していることが原因と考えられ 6)、第三種換気 システム運転時において躯体内部空間からの化学物質の室内侵入の 可能性が確認されている 7)。壁体内や床下空間における材料が適正 な温湿度環境にない場合、真菌の発生・増殖が考えられ、床下空間 の温湿度とカビ数との関係が明らかにされている ${ }^{8)}$

真菌に関しても非居室空間から居室に侵入寸る研究が進められ、 床部を通じた床空間からの空気の漏入によって微生物が居住空間に 運ばれていることが確認されている 9),10),11)。床下空間から床部を通 して居室に移動する真菌に関しては、空間の圧力差によって移動が 影響を受けることが指摘されている ${ }^{12)}$ 。また床下空間の温湿度、表 面温度、コンクリートの含水率、真菌濃度の 1 年間の測定から、冬 期は外気から床下に侵入したものが浮力換気によって室内一侵入し ていることが確認されている13)。壁体内に関しては、壁スタッド枠 内から室内への真菌胞子の移動を評価するために、実大の木材ス夕

\footnotetext{
* 長崎総合科学大学 教授·博士 (工学)

** 国立保健医療科学院 工博

$* * *$ 早稲田大学 教授.工博

**** 秋田県立大学 教授. 博士 (工学)

***** 宮城学院女子大学 教授·博士 (工学)
}

Prof., Nagasaki Institute of Applied Science, Dr. Eng.

National Institute of Public Health, Dr. Eng.

Prof., Waseda University, Dr. Eng.

Prof., Akita Prefectural University, Dr. Eng.

Prof., Miyagi Gakuin Women's University, Dr. Eng. 
ッドを用いて評価されている ${ }^{14)}$

これら非居住空間からの居室への侵入は、内外温度差や機械換気 などによる差圧の発生によるものと考えられる。計画換気を目的に 自然給気口が設けられていた場合においても、建物の相当隙間面積 との関係から、第三種換気・㕌房レンジフードなどの運転により、 コンセントプレートや建物隙間を通って非居住空間から居室に真菌 が漏入する恐れがある。また冬期の暖房運転により内外温度差が発 生した場合には、2 階の壁面や天井面を通って居室空間から天井裏 などの非居住空間へ真菌が漏出することになる。このようにコンセ ント部などの隙間を通じて居室と非居住空間との空気の漏入・漏出 が生じることが推測される。

この非居住空間内である壁体内部の真菌の状態を測定することは 重要であると考える。真菌の採取法に関しては、エアサンプラーを 用いる方法以外に、リアルタイムで測定する方法などが検討されて いる 15)ものの、壁体内真菌の採取法に関しては、コンセントの隙間 を経由させエアサンプラーを用いて躯体内部空間の空気を直接吸引 して真菌を採取する方法が用いられている ${ }^{16)}$ これは壁など内装材 を壊すことなく壁体内部の真菌を測定する方法として有効であると 考えるが、躯体内部空間の通気性状に影響を及ぼすことが考えられ ることから、壁体内の通気状態を大きく変えることなく空気を採取 する方法、すなわち狭小開口スペースを介して採取する方法である チューブを用いた採取法の導入が好ましい。この採取法としては、 取り扱いが簡単で柔軟なテフロンチューブを使って身体内部空間の 真菌を採取する方法が有効な手法の一つと考える。

本研究は、繊維系断熱材内部の真菌の移動を明らかにするために PDA 培地の真菌を用いた発生方式を検討した上でテフロンチュー ブを用いた採取方式の検討及び局所換気運転を想定した空気移動時 の断熱材内部の真菌胞子の移動に関する実験を行った。

\section{2. 実験概要}

断熱材内部の真菌の採取法と移動性状の確認を目的として、真菌 の発生方法を検討した上で、テフロンチューブとフィルターユニッ トを用いた採取法の適用範囲を検討した後に断熱材内の真菌の移動 に関して実験を行った。

\section{1 気中発生真菌発生方式の検討}

\subsection{1 真菌発生方式}

真菌の断熱材への付着を考慮する際、気中への真菌の放出と断熱 材への付着を評価する必要がある。林らは、実際の真菌を污染物質 として使用している 12 )。また床部の隙間から侵入する真菌を考慮す る際の移動過程を明らかにした際、真菌を含む污染物質をアトマイ ザーを用いて放散させる方法が用いられている ${ }^{14)}$ 。しかし、アトマ イザーを用いた方式は安定的な濃度での発散を確実にする有効な方 法であるものの、断熱材への真菌への付着という観点から、より実 際に近い状況である培地に育成した真菌胞子を気中に供給する方式 を用いることが、より望ましいと考える。このため PDA 培地に真 菌を含むTween 生理食塩水を滴下し、育成したものをガラスチャン バーに導入し、清浄空気で供給する方式を検討した。

作成した真菌発生源を振動モーターの上に設置し、ガラスチャン バー（真菌発生チャンバー）内へ入れて密栓し、清浄空気である $\mathrm{N}_{2}$ ガスを供給し、真菌を発生させる方式を検討した。この際、清浄
空気の供給のみでは、粉じん計を用いた計測からは、真菌を観測す ることができなかったことから、チャンバー内に設置した振動モー ターを同時に運転する方式を用いることとした。

\subsection{2 発生真菌の作成}

PDA 培地(栄研化学株式会社 8-MR31) に真菌懸濁液を滴下し発 生真菌を作成した。9cm サイズの PDA 培地から、 $1.0 \mathrm{~cm} \times 1.0 \mathrm{~cm}$ の サイズを作成し、Cladosporium cladosporioides 真菌懸濁液 $(7.0 \times$ $10^{6}$ 個 $\left./ \mathrm{mL}\right)$ を $400 \mu \mathrm{L}$ を滴下させ、パラフィルムで密閉した後に $38^{\circ} \mathrm{C}$ の恒温槽で真菌が育成する状態まで培養させた。真菌縣濁液の 作成方法は、使用器具を滅菌した後に、メスフラスコに生理食塩水 $100 \mathrm{~mL}$ を入れ、マイクロピペットにて Tween 80 を $10 \mu \mathrm{L}$ を入れる ことで、 $0.01 \%$ Tween 生理食塩水を作成した。その後、斜面培地 の養斜面にある Cladosporium cladosporioides 胞子を白金耳でとり、 $0.01 \%$ Tween 生理食塩水に投入し、スターラーを用いて擋拌した。 真菌を混入した $0.01 \%$ Tween 生理食塩水を希釈し、10n 倍希釈によ り、1 $10^{6}$ 倍希釈液まで作成し、その後、それぞれの溶液をPDA 培地 に $1 \mathrm{~mL}$ の液を投入した $(\mathrm{n}=2)$ 。作成直後の溶液に加え、冷蔵庫で 保存した状態の作成 4 日後と作成 8 日間後の溶液をPDA 培地に滴 下した。本試験においては、壁体内部での真菌の養生を含め検討す る予定から、比較的高温になるであろう環境条件下での評価を想定 し、恒温槽での状態確認から雾囲気温度 $38^{\circ} \mathrm{C}$ で真菌の発育を確認し たことから、この温度を用いて恒温槽内にて養生し、育成後に真菌 数を計数した。その結果、1 $10^{6}$ 倍に希釈した懸濁液の真菌コロニー 数が作成日、作成 4 日後および作成 8 日間後の平均值がそれぞれ 7 個, 7 個, 8 個であったことから、懸濁液濃度の変化が少ないことを確 認し、測定した最小值である 7 個に希釈倍率を乗じて、懸濁液濃度 は $7.0 \times 10^{6}$ 個 $/ \mathrm{mL}$ とした。

\section{1 .3 気中への真菌発生状態の確認試験}

PDA 培地上に存在する真菌を発生源に用いる方法は、現実的な条 件に近いと思われるものの、発生量は時間的に変動することが想定 されることから、測定使用上の限界があると考え、その特徵の把握 を行った。

濃度推移の測定システムを Fig. 1 に示す。ガラスチャンバー内か ら放散した真菌胞子は、真菌発生チャンバーの二次側に置かれた円 筒チャンバーに導入され、この気中濃度をデジタル粉じん計(柴田科 学株式会社製 GT-521型)を用いて測定した。円筒チャンバーは鋼製 であり、 $\phi 6 \mathrm{~mm}$ の採取穴から濃度を測定した。空気の供給は、真 菌の污染を考慮して窒素ガスを用いた。マスフローコントローラー (コフロック株式会社製)を用いて $20 \mathrm{~L} / \mathrm{min}$ の流速に制御した。測定 は、円筒チャンバー内の真菌濃度が 0 程度まで低下寸るまで行った。

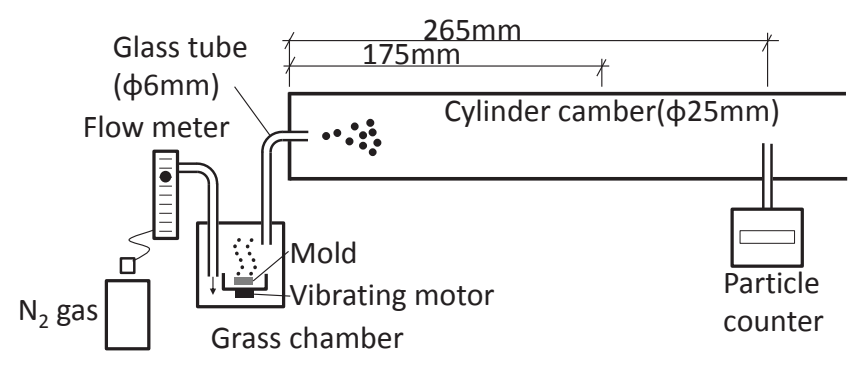

Fig.1 Experimental system 


\section{2 気中発生真菌採取方式の検討}

\section{2.1 採取方式}

壁体内真菌の採取法として、本研究においては、取り扱いが簡単 で柔軟なテフロンチューブを使って躯体内部空間の真菌を採取する 方法を検討した(Fig. 2)。本方式は、壁体内部空間の様な閉鎖空間か らの真菌採取のために必要な開口部が小面積で済む反面、テフロン チューブ内壁への真菌の付着による測定への影響が考えられる課題 がある。

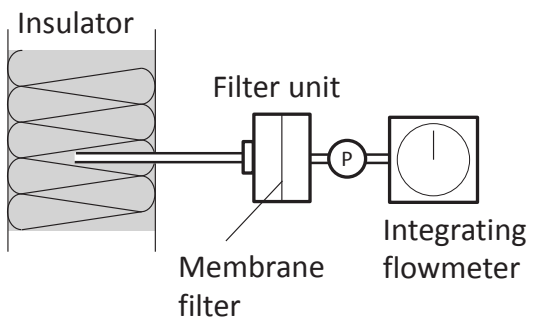

Fig.2 Mold sampling system

\section{2.2 テフロンチューブ内に付着・残留する真菌試験}

壁体内部の空気を非破壊で採取する方法としてテフロンチューブ を通してフィルターに捕集する採取法を検討した。この際、チュー ブ長が長い場合、チューブ内壁に真菌胞子が付着し、フィルターに 捕集された真菌数の計数值が誤った数值になる恐れがあることから、 現場での採取に活用可能な長さを求めるために、チューブ長さの別 による内部に残留した真菌を評価する方法を用いた。チューブ内へ の真菌の付着・残留を明らかにするために、真菌発生システムによ り真菌を所定時間発生させた状態でテフロンチューブに接続したフ イルターユニットを用いて空気を採取する。その後、フィルターユ ニットの真菌数とテフロンチューブ内付着真菌を Tween 滅菌生理 食塩水洗浄によって求めた真菌数を計数する評価方法を検討した。

\section{2. 2.1 テフロンチューブ内の残留真菌の採取方法}

テフロンチューブ内に付着残留する真菌を捕集する測定システム を Fig. 3 に示す。気中真菌採取方法であるテフロンチューブを介し たメンブレンフィルターに所定量空気を採取する際に、テフロンチ ユーブ内に付着残留する真菌とフィルターユニットまで到達する真 菌の割合からテフロンチューブの残留率を求めた。

使用したテフロンチューブ長さは、 $0.3 \mathrm{~m} 、 0.5 \mathrm{~m} 、 1.0 \mathrm{~m}$ である。 テフロンチューブおよびフィルターユニットを Fig. 4 に示す。チュ ーブを用いた空気中真菌捕集に関しては、円筒チャンバーにテフロ ンチューブを接続する穴を設け、ステンレス管を接続した。このス テンレス管にテフロンチューブを接続した。テフロンチューブの二 次側にメンブレンフィルター(EZ-Pak $47 \mathrm{~mm}$ 白色 $0.8 \mu \mathrm{m})$ をセッ トしたフィルターユニットを接続し、エアーポンプ(IWAKI 製 VPUMP-140 型) と積算流量計(株式会社シナガワ製 DC- $1 \mathrm{~A}$ 型)を接 続した。流量制御を行い $20 \mathrm{~L} / \mathrm{min}$ に制御した窒素ガスを真菌発生ユ ニットに流し、円筒チャンバー内へ供給した。デジタル粉じん計に て円筒チャンバー内の真菌濃度を測定しつつ、円筒チャンバー内の 污染空気をテフロンチューブを用いて 2 分間採取し、フィルターに より真菌を捕集した。同様の実験を長さ別に実施した。

テフロンチューブ内の残留真菌の測定は、Fig. 3 中(2)にあるよう
に Tween 生理食塩水にてテフロンチューブ内部を洗浄し、その真菌 胞子を含む洗浄液をステリフィルにセットしたメンブレンフィルタ 一を用いて捕集する方法を試みた。このメンブレンフィルターにて 捕集したものをPDA 培地上に移して、養生し計数した（Fig. 3 中 (3),Fig. 5)。テフロンチューブ内に付着・残留している真菌は Tween 滅菌生理食塩水洗浄で内部を洗浄し、1 回の洗浄回数では残留真菌 を除去できない恐れがあるため、複数回の洗浄を行い、その洗浄回 数を併せ検討した。気中の浮遊真菌胞子はフィルターユニットで捕 集した（Fig. 3 中(1) これら 2 種類の採取方法は異なるものの、チ ユーブ内の洗浄を複数回実施し、チューブ内部の真菌の残留が解消 することで、評価を行えると考えた。

テフロンチューブ内の洗浄方法は、テフロンチューブの一次側に 設置した滅菌生理食塩水が入ったイルリガートルから、 $1.0 \mathrm{~m}$ と $0.5 \mathrm{~m}$ の長さのテフロンチューブに対して 1 回 $100 \mathrm{~mL}$ の Tween 滅 菌生理食塩水でテフロンチューブ内部を洗浄し、これを、洗浄回数 別にステリフィルにて別々に捕集した。捕集した後のメンブレンフ イルターをPDA 培地上に移し、育成させ、真菌数を測定した。以 上洗浄回数と洗浄され捕集される真菌数の回数から必要な妥当な洗 浄回数を検討した。

\subsubsection{2 テフロンチューブ内部の真菌残留率}

テフロンチューブを通して捕集したフィルターユニット内のメン ブレンフィルターの真菌（Fig. 3 中(1)）とテフロンチューブを洗浄 し、ステリフィルのメンブレンフィルターに捕集した真菌（Fig. 3 中(3)）の比率から、真菌の残留率を求めた。テフロンチューブ内の 真菌残留率を(1)式に示す。

$$
\mu=\frac{C F U_{T}}{C F U_{F}+C F U_{T}} \times 100
$$

ここに、 $\mu$ : テフロンチューブ内残留率[\%]、 $\mathrm{CFU}_{\mathrm{F}}$ : フィルタ ーユニットで捕集された真菌数[CFU]、 $\mathrm{CFU}_{\mathrm{T}}$ : テフロンチューブ 内の残留真菌数 [CFU]

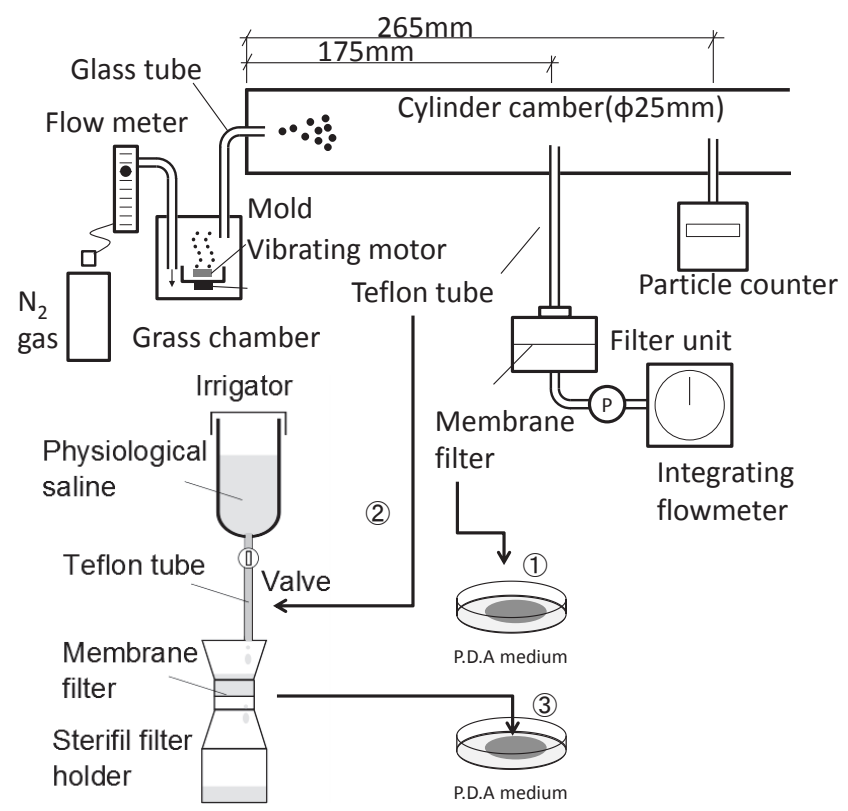

Fig. 3 Measurement system of mold retention 

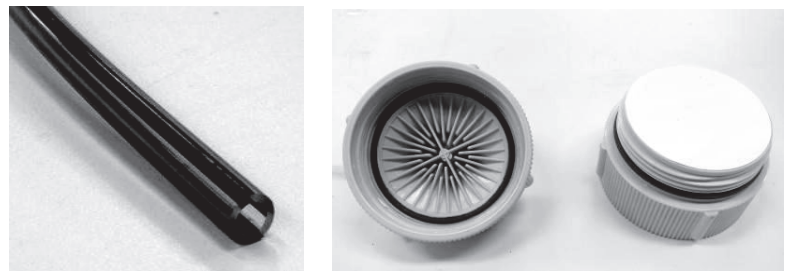

Fig. 4 Teflon tube, filter unit, and EZ-Pak membrane filter $(0.8 \mu \mathrm{m} 47$ $\mathrm{mm}$ )

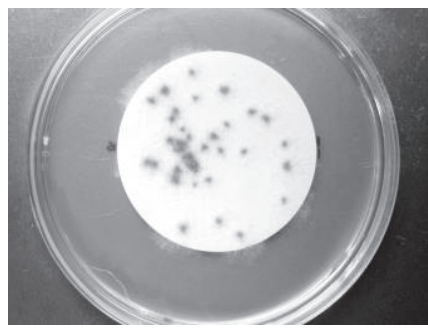

Fig. 5 Colonies of Cladosporium on the membrane filter

\section{3 繊維系断熱材内における真菌の移動性状試験}

断熱材中の真菌胞子の移動性状は、断熱材中の真菌量の測定法に 関する検討を行った上で評価した。真菌の拡散は、胞子の散布、胞 子の発芽成長、菌系体の形成、先端に胞子が形成、再び胞子の散布 の過程を経る。胞子の散布においては近傍気流による真菌胞子の移 動となると考えられる。このため、気流による真菌胞子の移動と、 断熱材に一旦付着した真菌胞子の気流による脱離・再移動の $2 つ の$ 面から移動性状を把握した。

断熱材内部の真菌の移動の評価に対して、2.1 に示す真菌発生装 置を用いた場合、発生量が時間と共に減衰する課題がある。また断 熱材内部を移動する真菌の速度との関係を踏まえる必要がある。 Airaksinen は床部を通した真菌の移動に関する評価に際し、アトマ イザーを用いた発生装置では定常状態での濃度評価が困難であった ため、構造を貫通する粒子のパーセンテージとして評価しており 12)、 時間的変動を考慮する測定手法が必要である。加えて実際の居住空 間に関してはコンセントなどの隙間を通じた壁体内部との真菌の移 動の駆動力は、24 時間換気システムに加えて局所換気などがあり、 比較的短時間の運転に伴って、壁体内部から空気の漏入が推定され る。以上、比較的短時間の強制換気による真菌胞子の流入と発生シ ステムにおける発生量の時間的変化から本実験では真菌の移動・付 着過程終了後に、測定対象断熱材に含む積算真菌数として扱うこと で時間的な発生量減衰の影響を少なくできると仮定し評価を行った。 すなわち、チャンバー内に所定の大きさにカットした断熱材を配置 し、真菌発生チャンバーを用いて発生させた真菌を含む空気を流通 させ、そのグラスウール中の総付着真菌数を計測することで移動性 状を調查した。

\section{3.1 断熱材洗浄回数の違いによる捕集真菌数の影響試験}

評価対象である断熱材内に付着寸る総真菌数は、滅菌生理食塩水 を用いて断熱材を洗浄することで求めた。この際、1 回の洗浄では 断熱材に付着した真菌胞子を完全に取り除くことができないことが 予想されたため、複数回の洗浄を行い、洗浄に必要とされる回数の 検討を行った。
断熱材に真菌を付着させた後に断熱材の洗浄を行った(Fig. 6)。真 菌が付着した断熱材を滅菌したビーカーに入れ (1 番目のビーカー)、 そこに Tween 滅菌生理食塩水を $200 \mathrm{ml}$ を入れた。そのビーカーを 振動機を用いて 5 分間振動させ、断熱材に付着した真菌を分離させ た。その後、ビーカー内の断熱材を絞り、断熱材内に水が残らない ようにした。次に、水分を出し切った断熱材を、次の新しい Tween 滅菌生理食塩水の入ったビーカー（2 番目）に入れ、再び振動機に よって 5 分間振動を与えた。その後、ビーカー内の断熱材を絞り、 断熱材内に水が残らないようにしつつ、次の $200 \mathrm{~mL}$ の Tween 滅菌 生理食塩水が入った 3 番目のビーカーに、水分を切った断熱材を投 入した。この動作を繰り返し行い断熱材内の真菌を Tween 滅菌生理 食塩水に取り出した。この行為を 5 回行い、1 番目から 5 番目まで の Tween 滅菌生理食塩水をマイクロピペットを用いて、 $1 \mathrm{ml}$ ずつそ れぞれ PDA 培地に移し、 $38^{\circ} \mathrm{C}$ の恒温槽で培養した。培養後目視に よって真菌数を計数し、 $200 \mathrm{~mL}$ の洗浄液との比率から、洗浄回数別 の断熱材内部の真菌数を測定した。

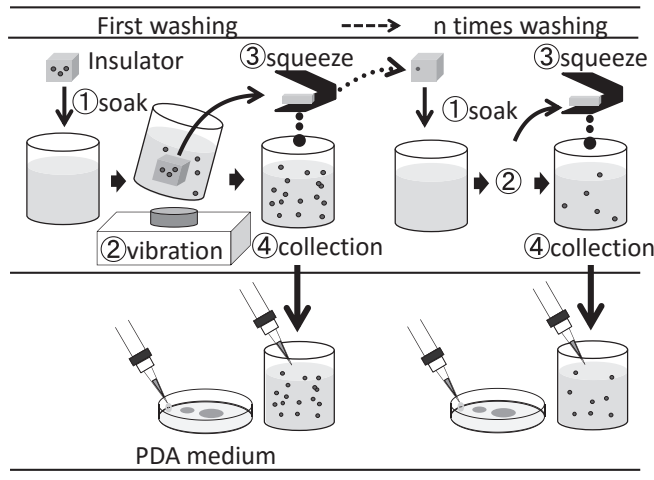

Fig. 6 Measurement of the amount of mold in a heat insulator

2. 3. 2 真菌発生システムを発生源として用いた真菌移動性状測定 真菌発生チャンバーを用いた断熱材中の真菌移動試験を行った。 実験装置を Fig. 7 に示す。また実験条件を Table 1 に示す。実験で 使用した小型チャンバーは $40 \mathrm{~mm}$ 角の断面をもつ長さ $550 \mathrm{~mm}$ のア クリル製チャンバーであり、内部はアルミシートを設置し、污染に 配慮した。

小型チャンバー内にあらかじめ分割した断熱材を配置し、HEPA フィルターを通して作成した清浄空気に真菌発生装置で発生させた 真菌を加えてチャンバー内に送り、断熱材に真菌を付着させた。風 速計を用いてアクリル管内部の風速を測定し、小型チャンバー内風 速を換算により求めた。

Table1 Heat insulator conditions

\begin{tabular}{l|l}
\hline Heat insulator & Glass wool $(10 \mathrm{~K})$ \\
\hline Heat insulator size & $40 \mathrm{~mm} \times 40 \mathrm{~mm} \times 40 \mathrm{~mm}$ \\
\hline Number of test specimen & 5 \\
\hline Velocity in the small chamber & $0.5 \mathrm{~m} \cdot \mathrm{s}^{-1}$ \\
\hline
\end{tabular}




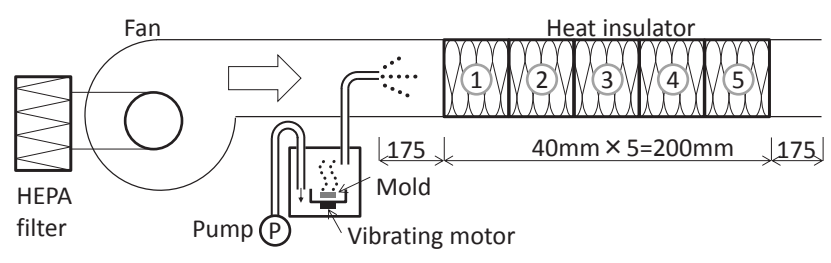

Fig. 7 Experimental system of mold movement in the heat insulator

使用した断熱材はグラスウールであり、これを小型チャンバー内 に設置した。グラスウールは流入端部より $175 \mathrm{~mm}$ の位置に設置し た（Fig. 7）。試験手順は、送風機(山洋電機株式会社製 San Ace B) の運転の後に、アクリル管内の風速を確認し、送風機運転開始後 20 秒後に真菌発生チャンバーの運転を開始し、真菌を放散させて小型 チャンバー内へと流し断熱材に付着させた。2 分間真菌の放散を行 った後に、測定システムを停止した。発生真菌システムは、Fig. 1 と同様である。この際、通過風速により移動性状が異なることが予 想されるためチャンバー内風速を $0.5 \mathrm{~m} / \mathrm{s} 、 0.2 \mathrm{~m} / \mathrm{s} 、 0.1 \mathrm{~m} / \mathrm{s}$ の 3 条 件を設定し実験した。断熱材の洗浄後、各部位で洗浄回数 3 回まで に作られた滅菌水をひとつのビーカーにまとめ、滅菌水 $1 \mathrm{ml}$ を PDA 培地に移し、 $38^{\circ} \mathrm{C}$ の恒温槽で培養を行った。培養後目視によって真 菌数を測定した。

\subsection{3 真菌付着断熱材を発生源として用いた真菌移動性状測定}

真菌胞子が付着した繊維系断熱材から真菌胞子が気流によって再 度離脱し、移動する可能性に関して評価するために、污染されてい る断熱材を放散源とした真菌胞子の移動試験を行った。実験条件・ 実験器具は「2.3.2」と同様のものを使用し、真菌発生源である断熱 材は、真菌発生装置を用いて真菌を付着させた断熱材を用いた(Fig. 8 中 部位(2), (4))。なお発生源である真菌付着断熱材の部位は、風 速条件 $0.2 \mathrm{~m} / \mathrm{s}$ 条件は、風速 $0.5 \mathrm{~m} / \mathrm{s}$ 条件に比較して、胞子の移動が 少ないと思われたため、図中に示寸部位(2)を、風速 $0.5 \mathrm{~m} / \mathrm{s}$ では部 位(4)を使用した。污染発生源である真菌付着断熱材を作成した後に、 その後方に真菌の付着していない 4 つの断熱材を配置した（図中(1) '〜(4)'。その後、送風機の運転を開始し、チャンバー内に 2 分間送 風することで、污染発生源である真菌付着断熱材からの真菌の脱離 状況を確認した。送風後、断熱材を洗浄・真菌の培養を行うことで、 (1) 〜 (4)' への真菌の移動を評価した。

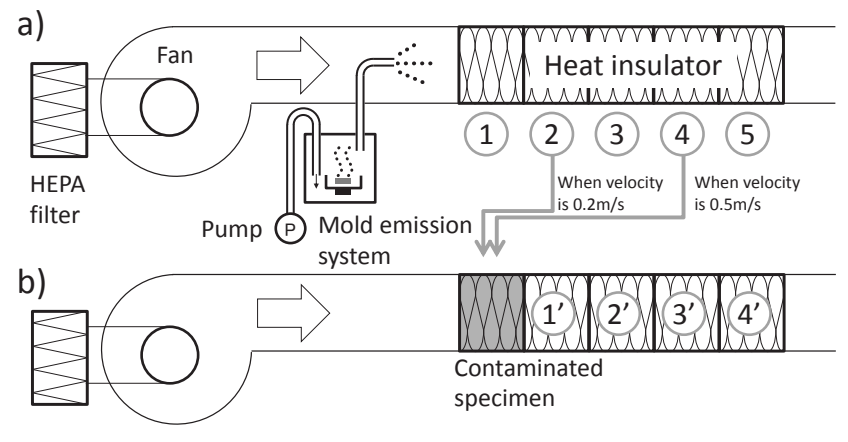

Fig. 8 Experimental system of mold movement

a) Making a contaminated heat insulator

b) Emission using a contaminated heat insulator

\section{3. 実験結果}

\section{1 真菌発生状態の確認試験}

真菌発生システムによる真菌濃度の結果の一例を Fig. 9 に示す。 振動モーターによる振動開始後の值を示す。真菌発生システムに空 気を供給した条件下では真菌の発生は見られず、振動モーターを用 いて強制的に振動を加えたときのみ真菌が確認されたことから、真 菌発生システムへの供給空気量では胞子の飛散はなく、物理的な刺 激が胞子の飛散には必要であることが分かった。

振動を加えた直後に急激に胞子の飛散が始まり、その濃度は 500CFU/L を超える高い值を測定した。しかし、その後急激に発生 量が低下し、600 秒程度経過した後は、ほとんど真菌を確認するこ とができなかった。これから PDA 培地上の胞子は、振動モーター の刺激で比較的容易に脱離することを示している。

この結果から、本真菌発生システムは時間的な変動があること、 および培地により発生量そのものが安定していないことが推定され た。従って、本真菌発生装置を利用する際には、急激な発生量変化 に対しても活用可能な、発生区間に対する積算放散量などを用いる ことが必要であると考える。

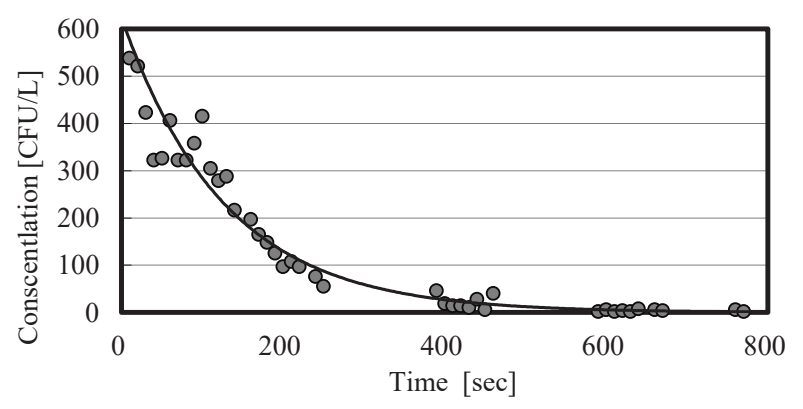

Fig. 9 Mold concentration in a cylinder chamber

\section{2 テフロンチューブ内の真菌の残留試験}

テフロンチューブ内への真菌の付着を確認するために、テフロ ンチューブ長さ $1.0 \mathrm{~m}$ と $0.5 \mathrm{~m}$ を用いて必要洗浄回数の検討を行っ た。ステリフィルからテフロンチューブ内を 3 回洗浄したときに洗 い流されたそれぞれの捕集真菌数を Fig. 10 に示す。

テフロンチューブ $1.0 \mathrm{~m}$ の場合、 1 回目の洗浄で $90 \mathrm{CFU}$ 洗い流さ れ、 2 回目に $8 \mathrm{CFU、3}$ 回目に $15 \mathrm{CFU}$ が流された。2 回目の洗浄よ りも 3 回目の洗浄で捕集した真菌が多くなったものの、1 回目の洗 浄で全体の $80 \%$ 近く捕集できた。同様に $0.5 \mathrm{~m}$ の場合、2 回目の洗 浄で僅かに真菌が捕集されたものの、3 回目以降の洗浄では真菌は 全く捕集されず、1回目の洗浄で全体の 90\%捕集した。長さが短い 方が適切に洗浄されることを示している。これより、0.5m のテフ ロンチューブを用いた場合、おおむね 1 回の洗浄で妥当な評価を行 うことができることが分かった。

次に、洗浄回数を 1 回としてテフロンチューブの長さ別のテフロ ンチューブ内の真菌残留率を求めた（Table 2)。テフロンチューブ の長さが長くなるごとに、テフロンチューブ内に残留する真菌の割 合が高くなった。 $0.3 \mathrm{~m}$ のテフロンチューブの場合、真菌残留率は およそ $5 \%$ 程度、 $0.5 \mathrm{~m}$ では、 $20 \%$ 程度、 $1.0 \mathrm{~m}$ においては、およそ $40 \%$ となった。このことから $0.3 \mathrm{~m}$ のチューブでは実用上問題がな いことが分かった。 


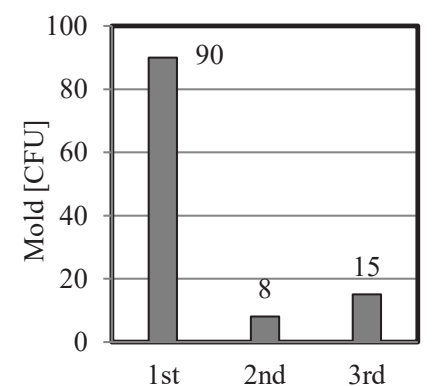

a) $1.0 \mathrm{~m}$

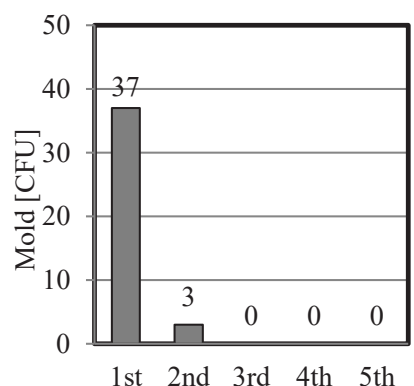

b) $0.5 \mathrm{~m}$
Fig. 10 Results of measuring the amount of mold inside a Teflon tube after washing

Table2 Results of measuring the retention rate in Teflon tubes of different length

\begin{tabular}{|c|c|c|c|c|c|c|c|}
\hline \multirow{2}{*}{$\begin{array}{c}\text { Teflon } \\
\text { tube } \\
\text { length } \\
{[\mathrm{m}]}\end{array}$} & \multirow[b]{2}{*}{ No. } & \multirow{2}{*}{$\begin{array}{l}\text { Sampling } \\
\text { volume } \\
{[\mathrm{L}]}\end{array}$} & \multirow{2}{*}{$\begin{array}{c}\text { Flow } \\
\text { rate } \\
{[\mathrm{L} / \mathrm{min}]}\end{array}$} & \multicolumn{2}{|c|}{ Mold [CFU] } & \multirow{2}{*}{$\begin{array}{c}\text { Retention } \\
\text { rate } \\
{[\%]}\end{array}$} & \multirow[b]{2}{*}{$\begin{array}{c}\text { Mean } \\
{[\%]}\end{array}$} \\
\hline & & & & Filter & $\begin{array}{l}\text { Inside } \\
\text { tube }\end{array}$ & & \\
\hline \multirow{2}{*}{0.3} & No.1 & 11.1 & 5.6 & 168 & 13 & 7 & \multirow{2}{*}{5} \\
\hline & No.2 & 11.0 & 5.5 & 111 & 3 & 3 & \\
\hline \multirow{2}{*}{0.5} & No.1 & 11.1 & 5.6 & 578 & 144 & 20 & \multirow{2}{*}{21} \\
\hline & No. 2 & 11.2 & 5.6 & 337 & 95 & 22 & \\
\hline \multirow{2}{*}{1.0} & No.1 & 11.1 & 5.5 & 211 & 121 & 36 & \multirow{2}{*}{38} \\
\hline & No. 2 & 11.0 & 5.5 & 43 & 27 & 39 & \\
\hline
\end{tabular}

\section{3 断熱空間内における真菌の移動性状試験}

\section{3. 1 断熱材の洗浄回数別の真菌数}

断熱材内部真菌数は断熱材を洗浄する方法を用いたため、必要洗 浄回数の検討を行った。洗浄回数ごとの洗浄真菌数測定結果を Fig. 11 に示す。洗浄回数が増すごとに、抽出される真菌数は減少し、洗 浄回数 5 回では約 1500 個と 0 回の時と比べて $1 / 10$ 程度となった。 このことから、洗浄回数を設定することで、断熱材中の真菌を測定 することの可能性がみられた。このため必要洗浄回数を明らかにす るために、得られた值を指数関数を用いて近似し式(2)を用いて真菌 排出率を求めた。

この真菌排出率の結果を Fig. 11 に併せて示す。この結果から、 洗浄回数 2 回目で約 $80 \% 、 3$ 回目で約 $85 \%$ を洗浄できていること がわかった。また、洗浄回数が多くなりすぎると目視によって確認 できる真菌数が少なくなり、正確な真菌数が得られないことから、 洗浄回数 3 回を洗浄回数として設定した。

$$
\mu=\frac{\int_{0}^{c} a \cdot e^{-b \cdot x} d x}{\int_{0}^{\infty} a \cdot e^{-b \cdot x} d x} \times 100
$$

ここに、 $\mu$ : 真菌排出率 $[\%] 、 \mathrm{c}:$ 洗浄回数 [回 $] 、 \mathrm{a}, \mathrm{b}:$ 係数 $[-]$

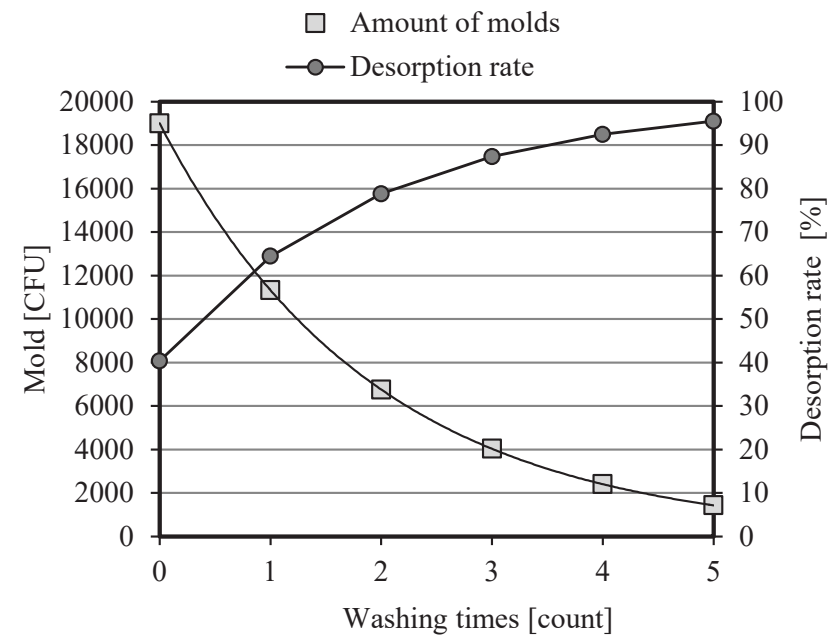

Fig. 11 Relationship of washing times and the amount of mold in the heat insulator $\square$ and desorption rate $\bigcirc$

\subsection{2 断熱材内の付着真菌数測定}

断熱材に付着している真菌を Tween 滅菌生理食塩水を用いて 3 回洗浄した方法により断熱材内部の付着している真菌数を求めた結 果を Fig. 12 (図中 部位(1)〜部位(5))に示す(断熱材の大きさ $40 \mathrm{~mm}$ の中央位置として各部材の位置を記載)。図は、部位(1)の中央位置で ある $20 \mathrm{~mm}$ から部位(5)中央位置である $180 \mathrm{~mm}$ における Tween 生理食塩水中に含まれる真菌数から逆算した含有真菌数を示したも のである。

風速 $0.5 \mathrm{~m} / \mathrm{s}$ 時の部位(1)（距離 $20 \mathrm{~mm}$ 部）に含まれていた真菌数 は 65,000 個程度であったが、部位(2)（距離 $60 \mathrm{~mm}$ 部）は 25,000 個、部位(3) (距離 $100 \mathrm{~mm}$ 部) は 13,000 個程度、部位(5) (距離 $180 \mathrm{~mm}$ 部）では 6,000 個程度であった。また $0.2 \mathrm{~m} / \mathrm{s}$ と $0.1 \mathrm{~m} / \mathrm{s}$ の条件にお いては、部位(1)に含まれていた真菌数は 25,000 個程度であったが、 部位(3)は 8,000 個、部位(5)では 5,000 個程度となり、部位(4)（距離 $140 \mathrm{~mm}$ 部）は異なった結果を示したものの真菌発生部からの距離 が大きくなるにつれて断熱材内に付着する真菌数は減少した。

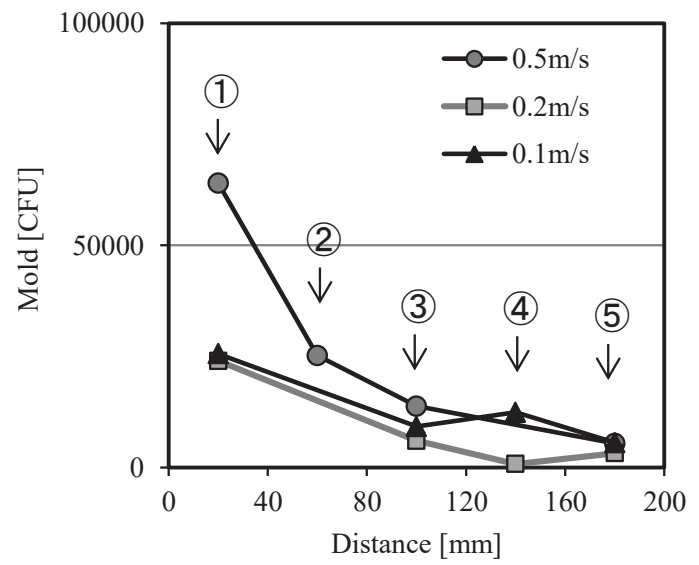

Fig. 12 Relationship between the distance and the amount of mold using mold emission system 
この結果から、断熱材中を通過する真菌に対して、濃度に依存せ

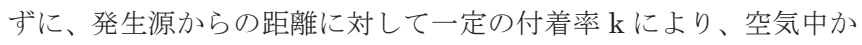
ら真菌が除去されるとすると所定の位置における濃度は式(3)とな

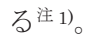

$$
C(x)=C_{0} e^{-k x}
$$

ここに、 $\mathrm{x}$ : 断熱材先端部からの距離 $[\mathrm{mm}] 、 \mathrm{C}:$ 真菌数 $[\mathrm{CFU}] 、$ $\mathrm{C}_{0}$ : 初期真菌数 $[\mathrm{CFU}] 、 \mathrm{k}$ : 吸着率 $[\mathrm{k}<1]$

今回の実験で得られた吸着率 $\mathrm{k}$ は風速 $0.5 \mathrm{~m} / \mathrm{s}$ では $0.15 、 0.2 \mathrm{~m} / \mathrm{s}$ では $0.16 、 0.1 \mathrm{~m} / \mathrm{s}$ では 0.08 であった。 $0.1 \mathrm{~m} / \mathrm{s}$ 時の結果が $0.5 \mathrm{~m} / \mathrm{s}$ および $0.2 \mathrm{~m} / \mathrm{s}$ と異なった理由は $140 \mathrm{~mm}$ 時点の付着真菌数が多かっ たためと思われた。この結果から得られた吸着率 $\mathrm{k}$ は風速の違いに より大きな差がみられず移動性状の差は少ないと考える。

以上から、今回使用した断熱材において真菌数は断熱材先端部か らの距離に影響を受けて減衰するものの、今回の風速程度の範囲の 場合、吸着率 $\mathrm{k}$ への影響が少ない結果となった。

\section{4 真菌付着断熱材を用いた移動性状測定}

次に、真菌付着断熱材を発生源として移動を評価した結果を Fig. 13 に示す。発生源である真菌付着断熱材 (Fig. 8 中 b) の位置を $0 \mathrm{~mm}$ から始まっているとして、その中央位置 $20 \mathrm{~mm}$ の位置に表現した。 移動対象である断熱材(2) 以降は、それぞれの中央位置である $60 \mathrm{~mm}, 100 \mathrm{~mm}, 140 \mathrm{~mm}, 180 \mathrm{~mm}$ においた。

送風 $0.5 \mathrm{~m} / \mathrm{s}$ 条件、 $0.2 \mathrm{~m} / \mathrm{s}$ 条件の両方の条件において、発生源で ある真菌を含む断熱材以外の断熱材（20mm 以降）は、発生源であ る真菌を含む断熱材に比較して、付着する真菌数が非常に少なく、 また断熱材先端からの距離が変化しても真菌数は変化せず、低い值 を示した。

この結果から、一旦繊維系断熱材に付着した真菌胞子は気流によ って再度脱離し、移動する可能性は低いと思われた。

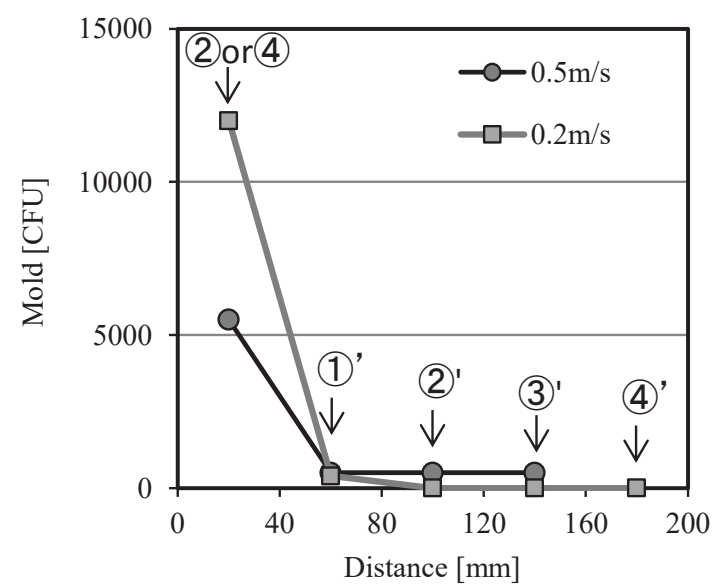

Fig. 13 Relationship between the distance and the amount of mold using a contaminated heat insulator

The contaminated heat insulator is part no.(4) and part no. (2) when the velocity is $0.5 \mathrm{~m} / \mathrm{s}$ and $0.2 \mathrm{~m} / \mathrm{s}$, respectively

\section{4. まとめ}

本研究は、断熱空間内の真菌採取法に関する実験によって分析を 行い以下の結果を得た。

1 ）テフロンチューブを用いた採取法では、テフロンチューブ内の 真菌残留率は長さが長くなるほど高くなる。テフロンチューブ 長さが $1.0 \mathrm{~m}$ では真菌残留率が $40 \%$ 近くであり、実用性に乏し い。しかし、0.3m では $5 \%$ 程度の残留程度であるため、天井や 床下に対して、限られたスペースからアクセスをして空気を採 取する方法として有効である。

2）断熱材に付着した真菌数を洗浄により求める方法を検討した結 果、洗浄回数は 3 回が妥当であることが分かった。

3 ) 断熱材中の付着真菌数を評価した結果、空気中に漂っている真 菌の断熱材内の移動および断熱材への付着は、真菌発生部から の距離が遠くなるほど指数関数的に少なくなった。そのため実 際の建築物では壁体の外側や屋内の污染源付近から污染が進ん でいくことが推測された。

$4 ） 今$ 回の風速の条件範囲では、断熱材の吸着率 $\mathrm{k}$ は風速に影響を 受けにくいことが分かった。

5 ）断熱材に付着した真菌を発生源とした送風による真菌胞子の移 動実験から、発生源に含まれる真菌胞子数に比較して風下側の 断熱材に含まれる真菌数は非常に少ない值であった。このこと から、一度断熱材に付着した真菌胞子は、例えば厨房換気扇な どの運転による負圧による気流の発生が行われた場合において も、実験の風速範囲の場合、室内に流入しないと考えられた。

\section{謝辞}

研究に際し、真菌に関する全般的な知見をご教授頂くとともに対 象真菌を提供して頂きました大阪市立自然史博物館 濱田信夫先生 に感謝する。また本研究の実験の一部は、平成 $27 \sim 30$ 年度文部科 学省科学研究費補助金（基盤研究(A) : 居住スタイル及び住宅性能・ 設備の変化を考慮した潜在健康リスク推定とリスク管理, 研究代表 者 林 基哉 国立保健医療科学院）の補助を受けた。

\section{注}

注 1）断熱材中を通過する真菌に対して、濃度に依存せずに一定の付着率 $\mathrm{k}$ により、空気中から真菌が除去されるとすると、一定区間 $\Delta \mathrm{x}$ 通過前後の 真菌濃度の関係式は式(4)で示寸ことができる。これを解き、移動は式 (6) が導き出される。

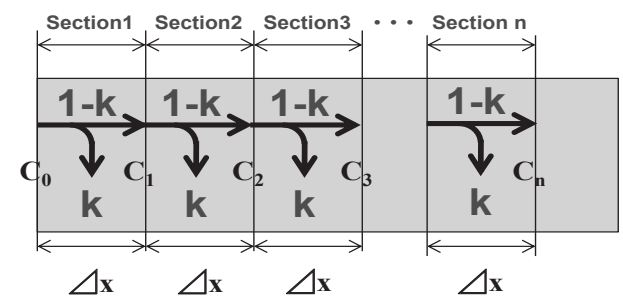

Fig. 14 Movement of mold spores between insulators

$$
\begin{aligned}
& C_{n+1}-C_{n}=-k \cdot C_{n} \cdot \Delta x \\
& C(x)=\lim _{n \rightarrow+\infty}\left(1-\frac{k \cdot x}{n}\right)^{n} \cdot C_{0}
\end{aligned}
$$


$C(x)=C_{0} e^{-l x}$

ここに、 $\mathrm{x}:$ 断熱材先端部からの距離 $[\mathrm{mm}] 、 \mathrm{C}:$ 真菌数 $[\mathrm{CFU}] 、 \mathrm{C}_{0}:$ 初期真菌

数 $[\mathrm{CFU}] 、 \mathrm{k}$ : 吸着率 $[\mathrm{k}<1]$

\section{参考文献}

1) Takashima, K.: ECOLOGICAL AND MYCOLOGICAL REVIEW ON THE FUNGI IN DWELLING ENVIRONMENTS, Japanese journal of allergology, 54(6), pp.531-535, 2005.6 (in Japanese)

高鳥 浩介: 生活環境中の真菌とその生態, アレルギー, 54(6), pp. 531-535, 2005. 6

2) Abe, K. and Kawahima, Y.: Relation of computed and measured fungal indices to airborne fungi, Summaries of Technical Papers of Annual Meeting, Architectural Institute of Japan, D-II, pp. 875-878, 2008. 7 (in Japanese)

阿部 恵子, 川上 裕司: 予測カビ指数・実測カビ指数と浮遊真菌の関係に ついて, 日本建築学会大会学術講演梗概集, D-II, pp. 875-878, 2008. 7

3) Abe, K. and Nakai, S.: Computed fungal index in room environment, Summaries of Technical Papers of Annual Meeting, Architectural Institute of Japan, D-II, pp. 889-890, 2006.7 (in Japanese)

阿部 恵子，中井 里史：室内環境におけるカビ指数の予測: 微生物による 室内空気污染, 日本建築学会大会学術講演梗概集, D-II, pp. 889-890, 2006. 7

4) Hayashi, M., Osawa, H. and Kusaka, A.: Field Study on Mold, Mites and Environmental Factors in houses: Part 3. Living and Numbers of Mold and Mites, Summaries of Technical Papers of Annual Meeting, Architectural Institute of Japan, D-II, pp. 901-902, 2007.7 (in Japanese) 林 基哉, 大澤 元毅, 日下 彩: カビ・ダニの実態と建築的要因に関する調 查研究: その 3 住まい方とカビ・ダニ数, 日本建築学会大会学術講演梗概 集, D-II, pp. 901-902, 2007. 7

5) Sugawara, F.: EFFECT OF TEMPERATURE AND HUMIDITY CONDITIONS TO GROWTH SPEED OF FUNGI ON BUILDING MATERIALS, Journal of Architecture, Planning and Environmental Engineering (Transactions of AIJ), No. 441, pp. 9-13, 1992. 11 (in Japanese)

菅原 文子: 建材上のカビの成長速度に与える温湿度の影響, 日本建築学 会計画系論文報告集, No. 441, pp. 9-13, 1992. 11

6) Hayashi, M. and Osawa, H.: MEASUREMENTS ON INFILTRATION ROUTS OF CHEMICAL COMPOUND FROM THE CONCEALED BUILDING MATERIALS: Infiltration network of detached houses with a common wood construction and a wood frame construction, Journal of Environmental Engineering (Transactions of AIJ), No. 675, pp. 375-382, 2012. 5 (in Japanese)

林 基哉, 大澤 元毅: 内部建材からの化学物質の室内侵入経路に関寸る測 定：木造軸組構法と木造枠組壁構法の戸建住宅の隙間ネットワーク, 日 本建築学会環境系論文集, No. 675, pp. 375-382, 2012.5

7) Hayashi, M. and Osawa, H.: INFLUENCE OF CHEMICAL EMISSION FROM CONCEALED BUILDING MATERIALS UPON INDOOR AIR QUALITY: Infiltration ratios to indoor spaces from concealed spaces in detached houses, Journal of Environmental Engineering (Transactions of AIJ), No. 676, pp. 375-382, 2012. 6 (in Japanese)

林 基哉, 大澤 元毅: 内部建材の化学物質放散が室内空気質に与える影 響: 戸建住宅の構造内部空間から室内空間への侵入率, 日本建築学会環境 系論文集, No. 676, pp. 499-506, 2012. 6

8) Hasegawa, K., Hayashi, M., Honma, Y. and Osawa, H.: A Study on Influence of Air Flow in Structure upon Indoor Air Quality: Part.2 Annual Change of Molds, Temperature and Humidity in a Crawl Space, Summaries of SHASE, pp. 1357-1360, 2008. 8 (in Japanese) 長谷川 兼一, 林 基哉, 本間 義規, 大澤 元毅: 住宅の躯体内部通気が室 内空気環境に与える影響に関する研究：その 2 床下空間におけるカビ数と 温湿度の年間変動, 社団法人空気調和・衛生工学会 学術講演会論文集, pp. 1357-1360, 2008. 8

9) Matilainen, M. and Pasanen, P.: Transport of fungal spores from crawl space to indoors, Proceedings of 9th International Conference on Indoor Air Quality and Climate, pp. 736-741, 2002. 6
10) Hayashi, M., Osawa, H., Hasegawa, K., Honma, Y. and Yamada, H.: Infiltration of Mold from Crawl Space under the Prefabricated Bathroom, Journal of Environmental Protection, Vol.5, pp914-921, 2014. 7

11) Hayashi, M., Osawa, H., Hasegawa, K., Honma, Y. and Yamada, H.: Experiments on Infiltration of Mold from Crawl Space under the Prefabricated Bathroom, CLIMA '2013 -11TH REHVA World Congress \& 8TH International Congress on IAQVEC, Id:296, 2013. 6

12) Airaksinen, M., J. Kurnitski, P. Pasanen, and O. Seppanen.: Fungal Spore Transport through a Building Structure, Indoor Air 14(2), pp. 92-104, 2004

13) Honma, Y., Hayashi, M., Hasegawa, K., Osawa, H. and Yamada, H.: The Relationships between the Indoor Air Pollution and the Air Quality in the Crawl Space using Full-Scale Experimental House, CLIMA '2013 -11TH REHVA World Congress \& 8TH International Congress on IAQVEC, Id:428, 2013. 6

14) Rao, Jiwu, Paul Fazio, Karen Bartlett and Dian Qing Yang: Experimental Evaluation of Potential Transport of Mold Spores from Moldy Studs in Full-Size Wall Assemblies, Building and Environment 44(8), pp. 1568-1577, 2009

15) Yanagi, U., Ikeda, K. and Abe, K. Application of the Instantaneous Microbial Detection in Measurement of Airborne Microbial Particles.: Part3, the response characteristics over viable and non-viable particles, Summaries of Technical Papers of Annual Meeting, Architectural Institute of Japan, D-II, pp. 905-906, 2007. 7 (in Japanese)

柳 宇, 池田 耕一, 阿部 恵子: 空中浮遊微生物粒子の測定における瞬間微 生物検知器の適用に関寸る研究: 第 3 報 生物粒子と非生物粒子に対する 応答特性, 日本建築学会大会学術講演梗概集, D-II, pp. 905-906, 2007. 7

16) Osawa, H., Hayashi, M., Hasegawa, K. and Honma, Y.: A Study on Influence of Air Flow in Structure upon Indoor Air Quality: Part 1. Annual Change of Molds in Indoor Spaces and Wall Spaces, Summaries of Technical Papers of Annual Meeting, Architectural Institute of Japan, D-II, pp. 895-896, 2008. 7 (in Japanese)

大澤 元毅，林 基哉，長谷川 兼一，本間 義規：住宅の躯体内部通気が室 内空気環境に与える影響に関する研究：その 1 室内と壁内空間のカビ数年 間推移, 日本建築学会大会学術講演梗概集, D-II, pp. 895-896, 2008. 7 


\title{
A BASIC STUDY ON CHARACTERISTICS OF MOLD MOVEMENT IN GLASS WOOL HEAT INSULATING MATERIALS
}

\author{
Hiromi YAMADA*, Motoya HAYASHI**, Shin-ichi TANABE***, \\ * Prof., Nagasaki Institute of Applied Science, Dr. Eng. \\ * National Institute of Public Health, Dr. Eng. \\ *** Prof., Waseda University, Dr. Eng. \\ **** Prof., Akita Prefectural University, Dr. Eng. \\ ***** Prof., Miyagi Gakuin Women's University, Dr. Eng.
} Haruki OSAWA ${ }^{* *}$, Ken-ichi HASEGAWA ${ }^{* * * *}$ and Yoshinori HONMA ${ }^{* * * * *}$

Currently, most detached houses in Japan are airtight wooden structures that have a high risk of vapor condensation in the wall cavities. Vapor condensation in insulation material is a primary contributor to mold growth in wall cavities. Indoor mold concentrations depend not only on indoor mold sources, but also on infiltration from concealed spaces, such as beam space and crawl space. The air pollutants infiltrate houses from these spaces by indoor decompression via the ventilation system, and mold that infiltrates through the glass wool used for heat insulation may remain and grow on the material. In order to measure the mold concentrations in glass wool, a new method is required for air cavity sampling. A method using a Teflon tube inserted into thin spaces in wall cavities or crawl spaces is useful for accomplishing this task. The surface of Teflon is very smooth, but mold adheres to it because of friction or static electricity. The objectives of the present investigation were to develop a method to measure mold concentration using Teflon tubes and to characterize the movement of mold spores between heat insulators.

The following conclusions were obtained from this study:

(1) The mean rates of mold retention in $0.3,0.5$, and $1.0 \mathrm{~m}$ Teflon tubes, which were washed three times with sterilized physiological salt solution, were $5 \%, 21 \%$, and $37 \%$, respectively. This indicated that retention rates increase with increases in Teflon tube length, and it was concluded that a useful sampling method for concealed spaces must use a Teflon tube that is about $0.3 \mathrm{~m}$ long, given the retention rate. Data from inter-laboratory testing indicated that a Teflon tube that is $1 \mathrm{~m}$ long is unsuitable for this sampling method.

(2) The amount of mold spores in the glass wool heat insulator decreased the more it was washed using sterilized physiological salt solution to clarify the movement of mold spores. After the third wash, the desorption rate of mold spores in the glass wool was about $85 \%$, showing that three rounds of washing were required to measure the mold movement.

(3) Measurement of the movement of mold spores inside the heat insulator showed that the quantity of mold spores adhering to the heat insulator decreases exponentially with an increase in length of the Teflon tubes.

(4) In this range of the wind velocity, the movement of mold spores between insulators through the heat insulator is not significantly influenced by wind in the small chamber.

(5) The experimental results indicate that the quantity of mold spores displaced from the heat insulator by air transportation was not significant. 